\title{
Spatio-temporal variation in marine fish traits reveals community-wide responses to environmental change
}

\author{
Esther Beukhof*, Tim S. Dencker, Laurene Pecuchet, Martin Lindegren \\ Centre for Ocean Life, National Institute of Aquatic Resources (DTU Aqua), 2800 Kongens Lyngby, Denmark
}

\begin{abstract}
Marine ecosystems are exposed to a range of environmental and anthropogenic stressors, including climate change and overexploitation. A promising way towards understanding the impacts of such stressors on community composition is by considering species traits rather than species identity. Here, we describe the spatio-temporal dynamics in fish community traits using $>30 \mathrm{yr}$ of species abundance data from the North Sea combined with trait information on body size, life history, growth rate, reproduction and trophic level for demersal fish species in the area. We assessed whether the derived patterns and trends in community-weighted mean traits could be explained by a range of environmental stressors and fishing. Our results revealed strong spatial structuring and long-term changes in the trait composition of North Sea fish, with temporal changes not being uniformly distributed in space. Among the environmental drivers investigated, depth was one of the best predictors, primarily explaining the spatial variation in lifespan, growth rate, trophic level and fecundity. This can be explained by variables that co-vary with depth, e.g. temperature, seasonality, salinity and productivity. Finally, we found only weak relationships between fishing and the spatial variation of traits, suggesting that the spatial trait composition of the community is mostly determined by the environment. Yet, long-term changes in trait composition, primarily in body size, have previously been shown to be affected by size-selective fishing. Our study exemplifies how traits can be used to summarize complex community dynamics and responses to environmental and anthropogenic stressors as well as their usefulness for ecosystembased management.
\end{abstract}

KEY WORDS: Marine fish · Traits · Spatio-temporal · Community-weighted mean · North Sea · Community composition $\cdot$ Climate change $\cdot$ Fishing

\section{INTRODUCTION}

Marine ecosystems are exposed to a range of environmental and anthropogenic stressors, including climate change, habitat alterations and overfishing (Milennium Ecosystem Assessment 2005). Our knowledge on how marine organisms respond to these stressors is advancing (e.g. Link et al. 2010, van Denderen et al. 2014, Poloczanska et al. 2016, Ruppert et al. 2018), yet our ability to predict future changes in marine ecosystems and the services they provide is hindered by the variety of species responses and the

\footnotetext{
${ }^{*}$ Corresponding author: estb@aqua.dtu.dk
}

complexity of species interactions (Pörtner et al. 2014). The responses of marine fish communities to stressors, such as climate change and fishing, are typically examined by studying the impacts of stressors targeting individual species, functional groups or other kinds of species aggregates (Halpern \& Floeter 2008, Engelhard et al. 2011, Simpson et al. 2011). Other studies have examined changes in community structure using biodiversity metrics, size spectra or mean trophic level (Pauly et al. 1998, Daan et al. 2005, Coll et al. 2010, Wiedmann et al. 2014). Such traitbased approaches are commonly regarded as a way

() The authors 2019. Open Access under Creative Commons by Attribution Licence. Use, distribution and reproduction are unrestricted. Authors and original publication must be credited. 
forward to understand and predict changes in community structure and function (McGill et al. 2006, Violle et al. 2014). A trait is defined as any characteristic of an organism's phenotype that can be measured at the individual level and can be related to its life history, morphology, physiology, behaviour or phenology (Violle et al. 2007). Together, traits govern an organism's fitness by determining its feeding, growth, survival and reproduction (Litchman et al. 2013). Traits can also shed light on species-environment relationships, since traits largely determine which environments a species is capable of inhabiting and additionally, with which species it interacts and coexists (Verberk et al. 2013). Moreover, traits can be used to understand how species and communities respond to environmental and anthropogenic pressures or to management measures, as having certain traits will make a species more or less vulnerable to change or disturbance (Perry et al. 2005, Mouillot et al. 2013, Coleman et al. 2015). A particular focus in marine trait-based studies has been on the response of fish life history traits to size-selective fishing and climate change. Fish species with a large size, late maturity and long lifespan are the most vulnerable to fishing (Jennings et al. 1998), whereas smaller-sized species that mature early are the first ones to shift their distribution in response to increasing sea temperatures (Perry et al. 2005). Also at the community level, traitbased metrics, such as the community mean size, weight, lifespan or growth rate, have been demonstrated to change over time, thereby revealing structural changes in fish communities in response to fishing (Jennings et al. 1999a, Greenstreet \& Rogers 2006, Greenstreet et al. 2012, Coll et al. 2016) and climate change (ter Hofstede \& Rijnsdorp 2011, Frainer et al. 2017).

The North Sea fish community is one of the most heavily fished systems worldwide. The overexploitation of large predatory species, such as Atlantic cod Gadus morhua, in the 1980s and 1990s is one of the main causes of the observed decrease in the mean size of demersal fish (Greenstreet \& Hall 1996, Rice \& Gislason 1996, Bianchi et al. 2000, Daan et al. 2005) and of the reduction in the proportional biomass of large fish (known as the large fish indicator, LFI) (Greenstreet et al. 2011, Engelhard et al. 2015). At the same time, large-scale climatic changes in the late 1980 s led to increasing water temperatures, enhanced phytoplankton biomass and a shift in zooplankton community composition favouring small, lower trophic level fish species (Reid et al. 2001, Heath 2005, Beaugrand 2009, Kenny et al. 2009), while hampering recruitment of large, higher trophic level species such as cod (Beaugrand et al. 2003). Besides size and trophic level, changes in other community traits have been reported for the North Sea fish community, such as an increase in the community mean growth rate and a decrease in age and length at maturity, for which trends date back to the 1920s (Jennings et al. 1999a, Greenstreet \& Rogers 2006, Greenstreet et al. 2012). In the late 1990s, the European Commission initiated a fishing fleet reduction scheme and lowered the fishing quotas. A recent recovery in the LFI suggests that these management measures are successful (Engelhard et al. 2015), but as climate change continues, increasing water temperatures may counteract this recovery (ter Hofstede \& Rijnsdorp 2011, Baudron et al. 2014, Engelhard et al. 2015).

In addition to the temporal changes in fish community composition, the North Sea displays pronounced spatial variation in fish species composition (Daan et al. 1990, Callaway et al. 2002). In general, the shallow southern area (Fig. 1) is dominated by flatfish, and with increasing depth towards the north, roundfish become more abundant (Daan et al. 1990, Callaway et al. 2002). The deep waters of the Norwegian trench harbour yet another community, which is characterized by bentho-pelagic and even boreal-arctic species (Bergstad 1990, Daan et al. 1990). Studies that combined the spatial and temporal dynamics of the community have revealed that temporal changes are heterogeneous in space (Daan et al. 2005, Greenstreet \& Rogers 2006, Engelhard et al. 2015, Marshall et al. 2016, Frelat et al. 2017), which is often disregarded by management that treats the community as spatially homogeneous (Marshall et al. 2016).

In this study, we used long-term, spatially resolved survey data on fish species abundances and an extensive trait dataset to expand the current knowledge on fish community changes in the North Sea. The primary objectives of our study were (1) to describe how multiple fish community traits are distributed in both time and space, and (2) to identify the underlying responses of these traits to a range of environmental and anthropogenic stressors. We accomplished this by examining and comparing the temporal trends, spatial patterns and spatio-temporal dynamics across multiple fish community traits, including body size, life history, growth rate, reproduction and trophic level. We then assessed if any changes in the trait composition of the community have occurred in response to fishing, temperature or other environmental variables not thoroughly studied before. 


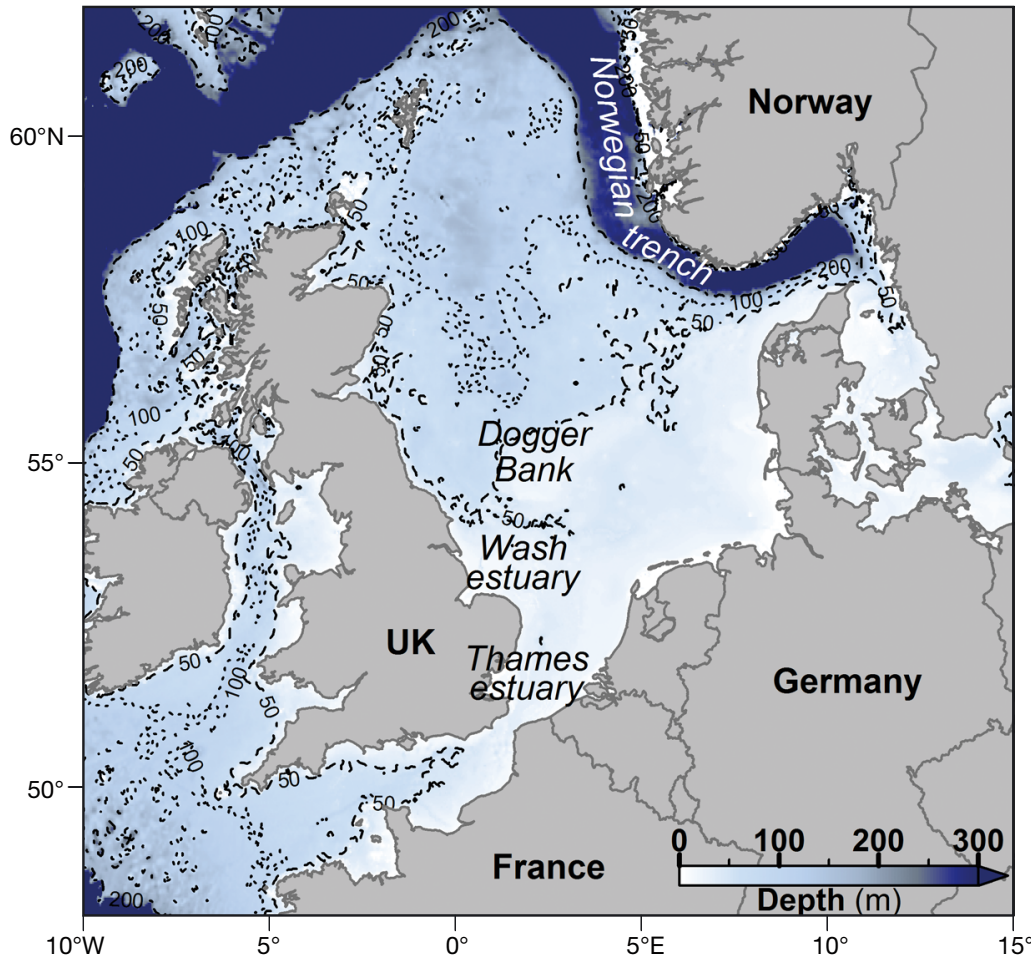

Fig. 1. Bathymetry and topography of the North Sea. Large dashes form the $50 \mathrm{~m}$ depth contour, small dashes the $100 \mathrm{~m}$ depth contour and mixed dashes the $200 \mathrm{~m}$ depth contour. Bathymetry data from Amante \& Eakins (2009)

\section{MATERIALS AND METHODS}

\subsection{Data collection and treatment}

\subsubsection{Survey data}

Fish community data were collected from the North Sea International Bottom Trawl Survey (NS-IBTS) that has been running during the first quarter of the year (January-March) with standardized gear since 1983 (ICES 2015). Data for the years 1983 to 2014 were extracted from the publically accessible database hosted by ICES (https://datras.ices.dk). Sampling is based on a stratification of $1^{\circ}$ longitude by $0.5^{\circ}$ latitude. The data consisted of catch per unit of effort, representing an indirect measure of species abundance in number of individuals caught per hour of fishing. The fishing gear used in the survey is the GOV trawl ('chalut à grande ouverture verticale'). Only hauls between 25 and 35 min and deeper than $20 \mathrm{~m}$ were kept to ensure similar sampling efforts and to remove strictly coastal species. In addition, we included only survey grid cells that were sampled in at least $80 \%$ of years to account for any kind of temporal variation between years, e.g. weather conditions (Hiddink \& ter Hofstede 2008). This resulted in 9552 unique hauls and 147 survey grid cells. Subsequently, pelagic fish were excluded, because the sampling does not adequately represent the abundance of pelagic fish relative to demersal. In addition, Heessen et al. (2015) were consulted to detect misidentifications or uncertainties in data reporting. Consequently, several taxa were either removed or combined at higher taxonomic levels (Table S1 in the Supplement at www.intres.com/articles/suppl/m610p205_supp.pdf). Records of taxa at the genus or family level were set at the species level when only 1 species from this genus or family was present in the dataset. Other records of taxa that were only reported at the family or genus level and for which no grouping was done (Table S1) were removed from the dataset. Finally, to ensure that the data represented resident rather than occasional and infrequent taxa, taxa present in less than 7 out of 32 yr were removed, leading to the exclusion of 58 out of 136 taxa that corresponded to only $0.002 \%$ of the total abundance. The resulting list consisted of 78 demersal fish taxa (henceforth referred to as species) that were retained in the analysis (Table S2 in the Supplement).

In order not to give a disproportionate weight to small and abundant species compared to larger and less abundant species, we converted the species abundance information to biomass. To obtain biomass estimates per species (in $\mathrm{g}$ ), the number of individuals per length class and haul were converted from length $(L)$ to weight $(W)$ using the equation $W=$ $a L^{b}$ where $a$ and $b$ are species-specific parameters. Parameter values were obtained from Fung et al. (2012), who calculated values from length-weight data collected during the NS-IBTS. Missing parameter values were extracted from Coull et al. (1989), Robinson et al. (2010), Verreycken et al. (2011) and Froese \& Pauly (2017). The derived biomass of each species was averaged per year, per survey grid cell and per combination of year and survey grid cell.

\subsubsection{Trait data}

Eight traits representing body size (length), life history and reproduction (age and length at maturity, lifespan, fecundity, offspring size), growth (Von Bertalanffy growth coefficient $K$ ) and position in the 
Table 1. Description and unit of the 8 fish traits chosen to characterize fish species in the North Sea

\begin{tabular}{|c|c|c|}
\hline Trait & Unit & Description \\
\hline Length & $\mathrm{cm}$ & Average length measured in survey; represents body size \\
\hline Trophic level & No dimension & $\begin{array}{l}\text { Calculated based on empirical observations of diet composition; represents } \\
\text { position in the food web }\end{array}$ \\
\hline Length at maturity & $\mathrm{cm}$ & $\begin{array}{l}\text { Length at which } 50 \% \text { of the population becomes mature; related to life history } \\
\text { strategy, energy allocation and growth }\end{array}$ \\
\hline Age at maturity & $\mathrm{yr}$ & $\begin{array}{l}\text { Age at which } 50 \% \text { of the population becomes mature; related to life history } \\
\text { strategy, generation time and growth }\end{array}$ \\
\hline Lifespan & yr & Maximum age; related to generation time and life history strategy \\
\hline Growth coefficient $K$ & $\mathrm{yr}^{-1}$ & $\begin{array}{l}\text { Rate at which maximum theoretical length is attained; based on Von Bertalanffy } \\
\text { growth equation; proxy for individual growth rate }\end{array}$ \\
\hline Fecundity & No. eggs $\mathrm{yr}^{-1}$ & $\begin{array}{l}\text { Mean number of eggs spawned female }{ }^{-1} \mathrm{yr}^{-1} \text {; related to reproduction strategy } \\
\text { and energy allocation }\end{array}$ \\
\hline Offspring size & $\mathrm{mm}$ & $\begin{array}{l}\text { Diameter size of eggs, length of egg case or body length of offspring; related to } \\
\text { reproduction strategy and investment in offspring }\end{array}$ \\
\hline
\end{tabular}

food web (trophic level) were included (Table 1). These traits represent different morphological, physiological and life-history aspects of fish ecology, primarily in terms of reproduction, feeding and growth that are known to be responsive to environmental and/or anthropogenic stressors (Pauly et al. 1998, Jørgensen et al. 2007). The growth coefficient $K\left(\mathrm{yr}^{-1}\right)$ was chosen as a proxy for individual growth rate. It is a parameter of the Von Bertalanffy growth equation (VBGE) that expresses body length as a function of time, $K$ and the theoretical maximum body length (length infinity; $L_{\infty}$ ). The growth coefficient $K$ determines how fast an individual approaches $L_{\infty}$. In addition, an alternative growth parameter was calculated that is independent of size, namely the growth rate $\omega$, proposed by Gallucci \& Quinn (1979). It is calculated by multiplying $K$ and $L_{\infty}$, which is the initial slope of the VBGE, and thus primarily represents juvenile

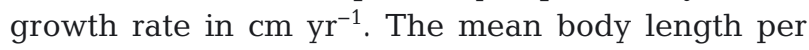
species was calculated using body length measurements from the survey, which were averaged over all hauls conducted in the survey and weighted by the biomass of each length class. Other trait values originated from primary literature and FishBase (Froese \& Pauly 2017). When available, values from the North Sea or adjacent regions were prioritized. When unavailable, trait values were inferred from closely related species present in the dataset. In cases were multiple trait values were reported, an average value was calculated. In addition, we used 1 trait value per species, despite the potential importance of intraspecific variation in traits (Alofs 2016, Ward et al. 2016). Trait values were also fixed throughout the study period, even though temporal changes in life history traits have been demonstrated in North Sea fish (Jørgensen et al. 2007). A species list with trait values and references is provided in Table S2 in the Supplement.

\subsubsection{Environmental and fishing effort data}

To study potential anthropogenic and environmental drivers of fish community traits in space and time, data on fishing effort and 6 environmental variables were collected per grid cell and year. Monthly sea bottom temperatures $\left({ }^{\circ} \mathrm{C}\right)$ and sea bottom salinities were extracted from Núñez-Riboni \& Akimova (2015). Average temperature and salinity in the first quarter were calculated per year and survey grid cell. As a metric of seasonality, the difference between mean winter (January-March) and summer (July-September) bottom temperatures per grid cell was used. Depth was taken as the mean sampling depth per survey grid cell. As a proxy for phytoplankton biomass during the first quarter, the phytoplankton colour index (PCI) was used, which is a measure of greenness in water samples from the continuous plankton recorder (CPR) (SAHFOS 2016). Since the sampling scheme of the CPR consists of transects not covering the entire area, missing values were interpolated using a generalized additive model (GAM). Thereafter, a mean PCI was calculated per year and per survey grid cell. Seabed substrates were available through the European Marine Observation Data network Seabed Habitats project (EMODnet 2015). For each survey grid cell, the number of different substrates present was summed to represent substrate richness. Finally, 2 datasets of 
international fishing effort in the North Sea for the periods 1990-1995 (Jennings et al. 1999b) and 20032012 (Engelhard et al. 2015) were used to calculate a mean beam trawl effort and otter trawl effort per survey grid cell. Trawl effort (in number of hours fishing) was estimated based on fishermen logbook data submitted to national administrations and the European Commission (Jennings et al. 1999b, Engelhard et al. 2015).

\subsection{Data analysis}

\subsubsection{Community-weighted mean of traits}

The community-weighted mean (CWM) of a trait is the average trait value in the community. It is based on the mass-ratio hypothesis, stating that dominant species are expected to have the largest impact on the structure and functioning of communities (Grime 1998, Garnier et al. 2004). When a CWM trait changes in either time or space, it typically indicates that the community has shifted in its structure, often as a response to changes in the environment or sudden disturbances (Mouillot et al. 2013). CWM traits are thus useful detectors of changes in structure by summarizing the overall response of a community based on the underlying species dynamics (Ricotta \& Moretti 2011). The majority of traits in our dataset showed a skewed distribution. Consequently, we calculated the CWMs of each trait as a geometric mean weighted by species biomass:

$$
\mathrm{CWM}=\left(\prod_{i=1}^{n} \text { trait }_{i}^{p_{i}}\right)^{1 / \sum_{i=1}^{n} p_{i}}
$$

where $n$ is the number of species, trait $_{i}$ is the trait value of species $i$, and $p_{i}$ is the relative biomass of species $i$. CWMs per trait were calculated according to 3 different spatial and temporal aggregations. First, to generate a time series of CWMs for each trait, CWMs were calculated based on spatially averaged species biomasses per year (i.e. averaged over all hauls per survey grid cell, and then averaged over all survey grid cells). Second, to get CWMs for each survey grid cell, CWMs were calculated using species biomasses averaged over all years. Finally, CWMs were calculated for each year in each survey grid cell. This last step allowed for examining spatiotemporal trends in CWM traits by constructing linear regression models for each time series of CWM traits in each survey grid cell using year as a predictor. The slope of the models indicated if there was a directional positive or negative change in the CWM trait over time in the respective survey grid cell. Note that strong non-linear dynamics will give slopes close to 0 , thereby indicating that over time no clear onedirectional change has taken place. Finally, principal component analyses (PCAs) were used to assess the similarities in temporal trends, spatial patterns and spatio-temporal trends between the traits.

\subsubsection{Assessing drivers of trait variation in space and time}

Using a statistical modelling approach, we then assessed the degree to which the variation in the derived time series and spatial patterns of CWM traits could be explained by the environment and fishing effort. The spatio-temporal CWM traits were not further assessed for their drivers. We used GAMs and generalized additive mixed models (GAMMs), as these classes of models allow for non-linear relationships between response and predictor variables (Wood 2006). The basis dimension $(k)$ for the smooth terms was restricted to 3 to limit the flexibility of model fitting and to reduce the risk of overfitting (Nogués-Bravo 2009). The temporal trends and spatial trait patterns were modelled separately, and the procedure for each is described below.

The time series of the 8 traits, consisting of $32 \mathrm{yr}$ (1983-2014), were the response variables for the temporal models, i.e. 1 model for each trait. As predictor variables, we included sea bottom temperature, sea bottom salinity, seasonality in sea bottom temperature and the PCI as annual averages over all survey grid cells. All variables had a variance inflation factor (VIF) <10, deemed as an acceptable degree of collinearity between predictors (Borcard et al. 2011). Because of the short time series of beam and otter trawling effort (16 yr), these variables were not included. For each time series of traits, a GAM that included all 4 predictor variables was constructed as follows:

$$
\begin{gathered}
\text { CWM trait } \sim \beta+s \text { (Temperature })+s \text { (Salinity) } \\
+s(\text { Seasonality })+s(\mathrm{PCI})+\varepsilon
\end{gathered}
$$

where $\beta$ is the intercept, $s$ is a smooth function, and $\varepsilon$ is the normally distributed error. We then tested for temporal autocorrelation of the model residuals. If present, a first-order autoregressive correlation structure (corAR1) was added to the model to account for temporal autocorrelation (Zuur et al. 2009). Since GAMs do not readily allow for correlation structures to be added, we therefore used a GAMM instead, including the corAR1 correlation structure with year as a 
factor. A dummy variable was set as a random effect in order for the model to operate. Since temporal autocorrelation was detected for the model residuals of trophic level and the growth coefficient $K$, GAMMs were only constructed for these 2 traits.

The spatial models had the CWM traits per survey grid cell as response variables. The predictor variables were depth, sea bottom temperature, sea bottom salinity, seasonality in sea bottom temperature, the PCI, substrate richness, beam trawl effort and otter trawl effort. All variables were averaged over years for each survey grid cell. Beam and otter trawling effort data contained many small values, as well as 0 s. Therefore, these data were $\log _{10}$-transformed after having added a value of 1 . The VIF of all predictors was $<10$, indicating an acceptable degree of collinearity between variables (Borcard et al. 2011). A number of survey grid cells (22 out of 147) were excluded from the analysis, because they lacked data on substrate richness and/or contained low values of salinity (coastal areas) that, when included in the analysis, had a disproportionate influence on the modelled relationships. For each trait, a GAM was constructed that included all possible predictor variables:

$$
\begin{gathered}
\text { CWM trait } \sim \beta+s(\text { Depth })+s(\text { Temperature }) \\
+s(\text { Salinity })+s \text { (Seasonality })+s(\mathrm{PCI}) \\
+s \text { (Substrate richness })+s \text { (Bottom trawl effort }) \\
+s(\text { Otter trawl effort })+\varepsilon
\end{gathered}
$$

where $\beta$ is the intercept, $s$ is a smooth function, and $\varepsilon$ is the normally distributed error. When testing for spatial autocorrelation of the model residuals using Moran's test (R package 'spdep'; Bivand et al. 2013, Bivand \& Piras 2015), all 8 models showed spatial autocorrelation. Therefore, a GAMM was constructed for each trait instead, including all predictor variables as fixed effects, a dummy variable as a random effect and a Gaussian spatial correlation structure using the longitude and latitude of the survey grid cells. Six out of 8 spatial trait patterns (length, age and length at maturity, lifespan, fecundity and offspring size) were $\log _{10}$-transformed to approach normally distributed residuals.

To assess the importance of the predictors of the temporal and spatial models, the relative variable importance (RVI) was computed for each predictor in each model. The RVI ranges from 0 to 1 and represents the probability of a variable ending up in the best fitting model. First, a set of models (with 1 to 4 predictors) was generated based on combinations of all predictor variables. The RVI for each predictor was then calculated as the sum of Akaike weights of the generated models that included the variable of interest (Burnham \& Anderson 2002). Model fitting and analysis were conducted using the 'mgcv' (Wood 2011) and 'MuMIn' (Barton 2016) packages in the $R$ software, version 3.4.0 (R Core Team 2017).

\section{RESULTS}

\subsection{Spatio-temporal patterns and trends in traits}

The CWMs of length, age and length at maturity, lifespan and fecundity demonstrated similar decreasing temporal trends (Fig. 2i) until the early 1990s, after which length, length at maturity and fecundity levelled off (Figs 2a,b,g) and age at maturity and lifespan increased again (Figs 2c,d). Trophic level decreased slightly but constantly (Fig. 2f), whereas the growth coefficient $K$ increased during the first 2 decades and fluctuated thereafter (Fig. 2e). Juvenile growth rate showed an opposite trend compared to $K$ with a decrease in CWM during the first half of the study period and a slight increase again thereafter (Fig. S1 in the Supplement), hence similar to the trend of age at maturity. No temporal trend was observed for offspring size, which primarily showed strong interannual fluctuations throughout the period (Fig. 2h).

Similar spatial patterns were found for length, length at maturity and age at maturity (Fig. 3i), with high values along the Norwegian trench and the south-western British coast, as well as a small area of intermediate values in the central North Sea (Figs. 3a-c). High values were observed in the same areas for lifespan, although with a more pronounced west-to-east gradient of increase in the central North Sea (Fig. 3d). Fecundity also showed high values along the Norwegian trench, whereas its lowest values were observed in the south-western North Sea around the Wash and Thames estuaries (Fig. 3g). Offspring size followed an opposite pattern, with low values along the Norwegian trench and high values in the south-western North Sea (Fig. 3h). A distinct pattern was observed for the growth coefficient $K$, with peak values in the central North Sea (Fig. 3e). Juvenile growth rate showed a similar spatial pattern, but with additional high values along the Norwegian trench (Fig. S1). Trophic level generally followed a south-east to north-west gradient of increase, with high values along the Norwegian trench and in the south-western North Sea (Fig. 3f).

The spatio-temporal trait patterns revealed predominantly significant negative temporal trends for the majority of traits (length, length and age at maturity, trophic level and fecundity), except for the 
a

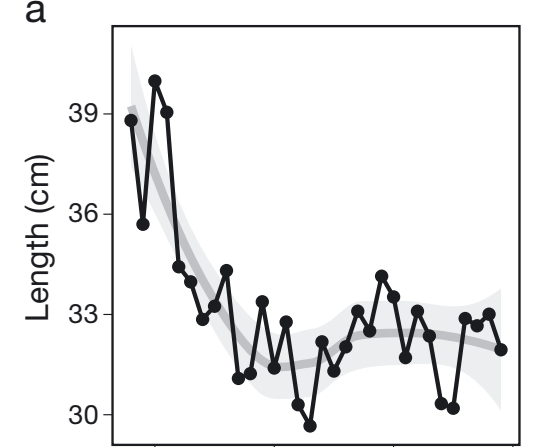

d
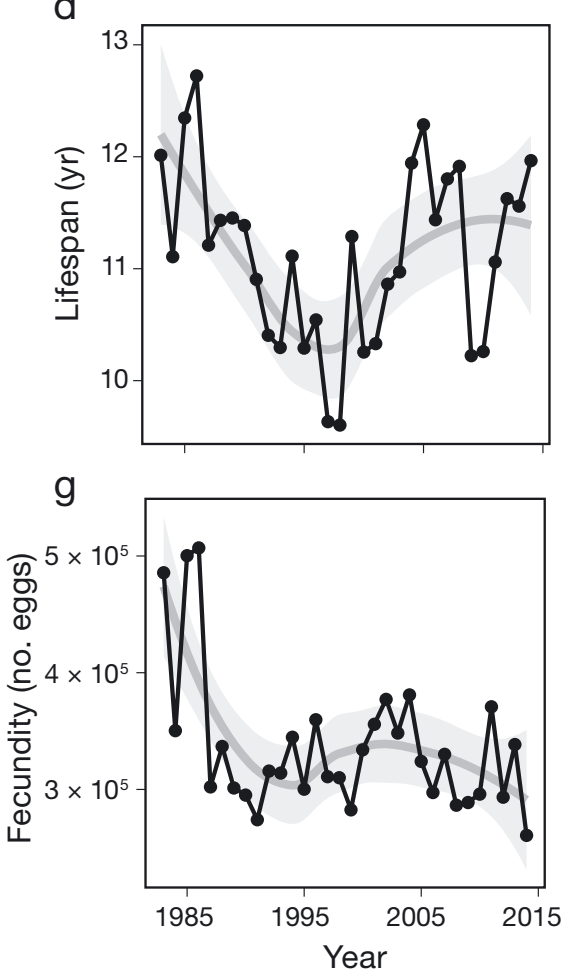

b
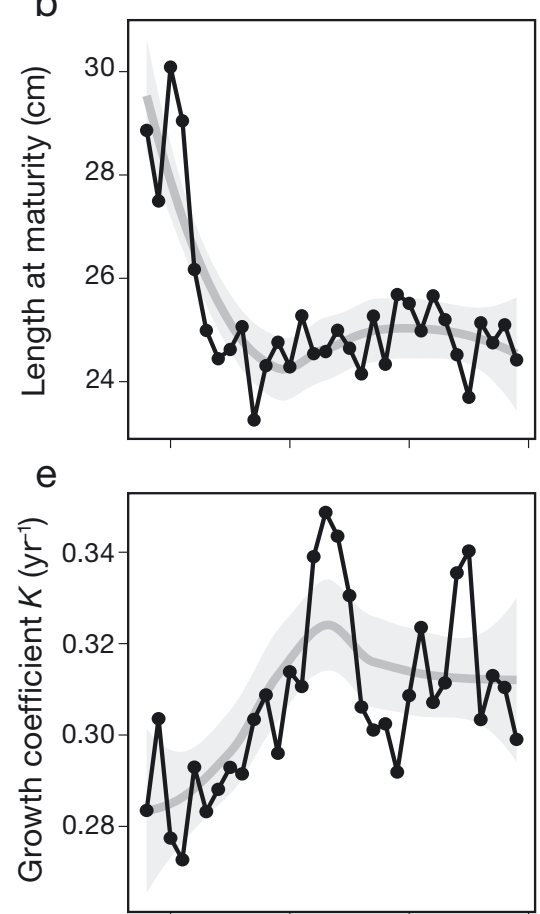

$\mathrm{h}$

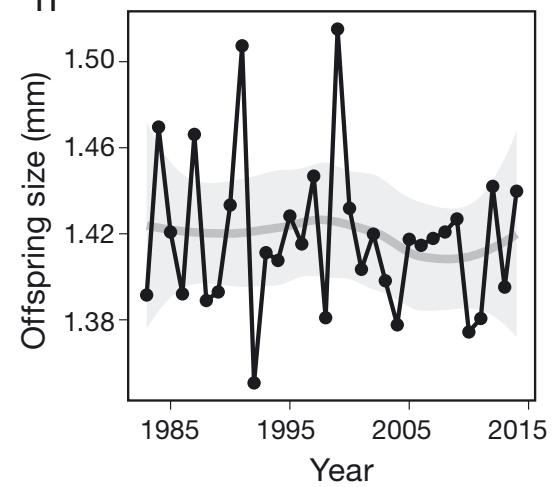

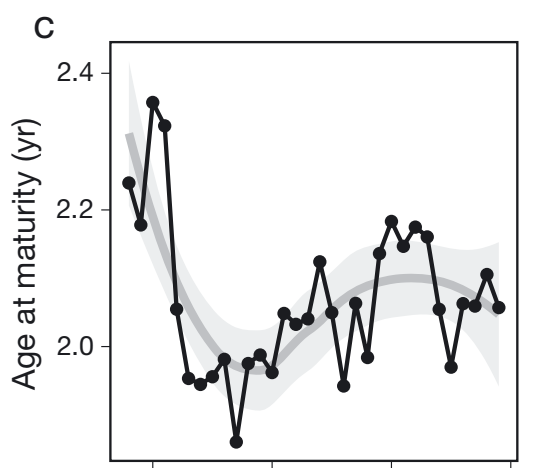
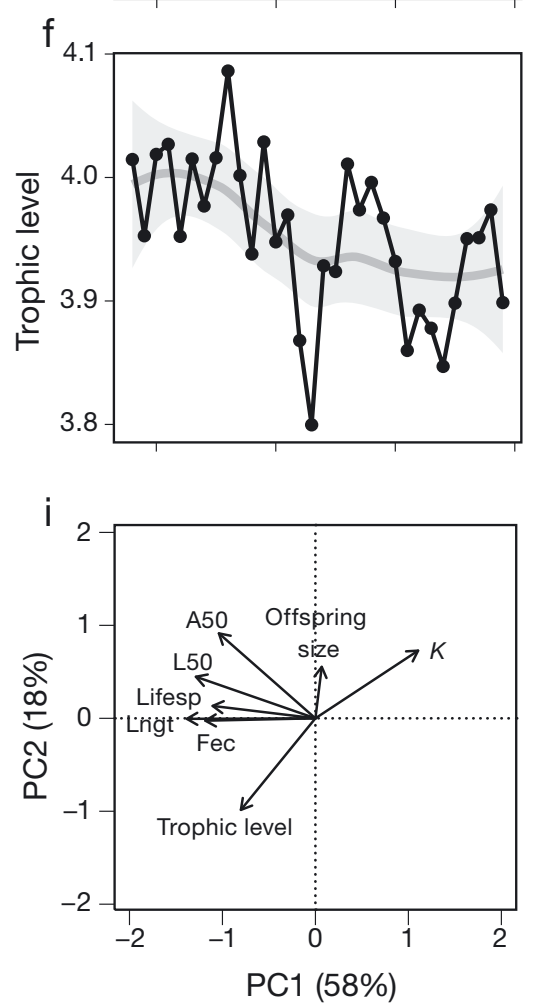

Fig. 2. Time series of the community-weighted mean (CWM) traits between 1983 and 2014, and principal component analysis of the 8 time series. Trend of the CWMs of (a) length, (b) length at maturity, (c) age at maturity, (d) lifespan, (e) growth coefficient $K_{,}(\mathrm{f})$ trophic level, (g) fecundity and (h) offspring size. Grey line with shaded area is a loess-smoother with confidence interval to visualize the main trend. (i) Ordination plot demonstrating the relationships between the 8 time series. First and second principal components (PC1, PC2) explained 58 and $18 \%$ of the variation, respectively. A50: age at maturity; L50: length at maturity; Lifesp: lifespan; Lngt: length; Fec: fecundity

growth coefficient $K$, which mostly showed positive trends over time (Fig. 4). Most significant negative trends were found in the central North Sea, whereas most insignificant trends were located in the northern or eastern parts. Age and length at maturity and lifespan had several survey grid cells with significant increasing trends, particularly in the northern North Sea (Fig. 4b-d). Likewise, juvenile growth rate showed increasing trends in the north, but also decreasing trends in the south (Fig. S1). Length, trophic level, length at maturity, growth coefficient $K$ and fecundity had the highest number of survey grid cells with significant temporal trends in CWM traits. Relatively few were detected for offspring size, lifespan and age at maturity.

\subsection{Drivers of fish community traits in time and space}

The temporal models for length, and age and length at maturity demonstrated the highest degree of explained deviance $\left(\mathrm{R}^{2}\right)$ of all traits (Table 2). To a lesser extent, fecundity and lifespan were also well ex- 


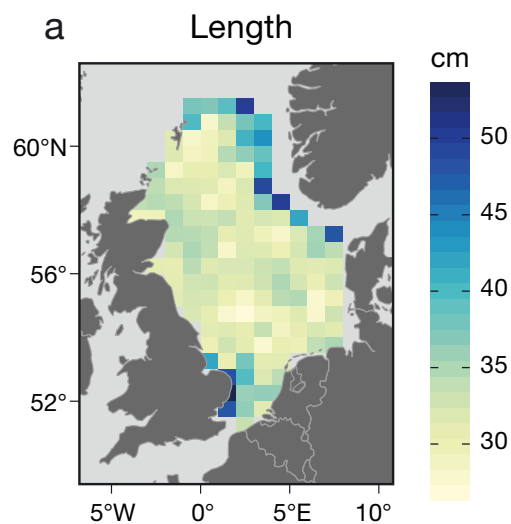

b Length at maturity

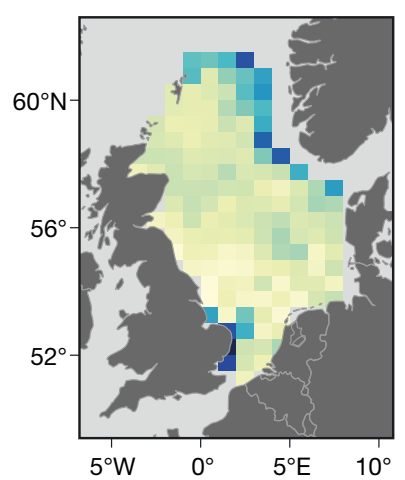

e Growth coefficient $K$
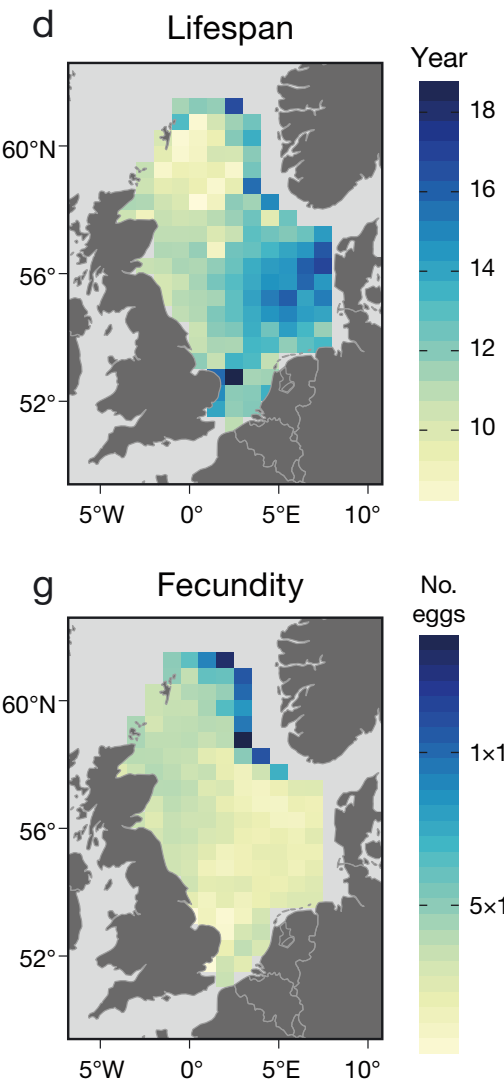

No.

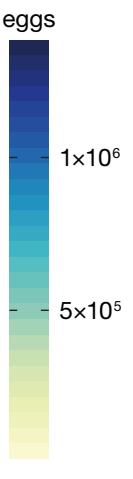

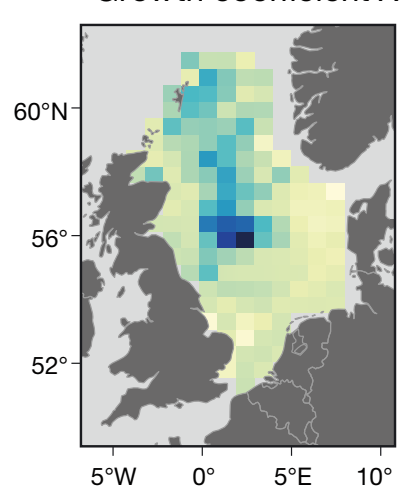
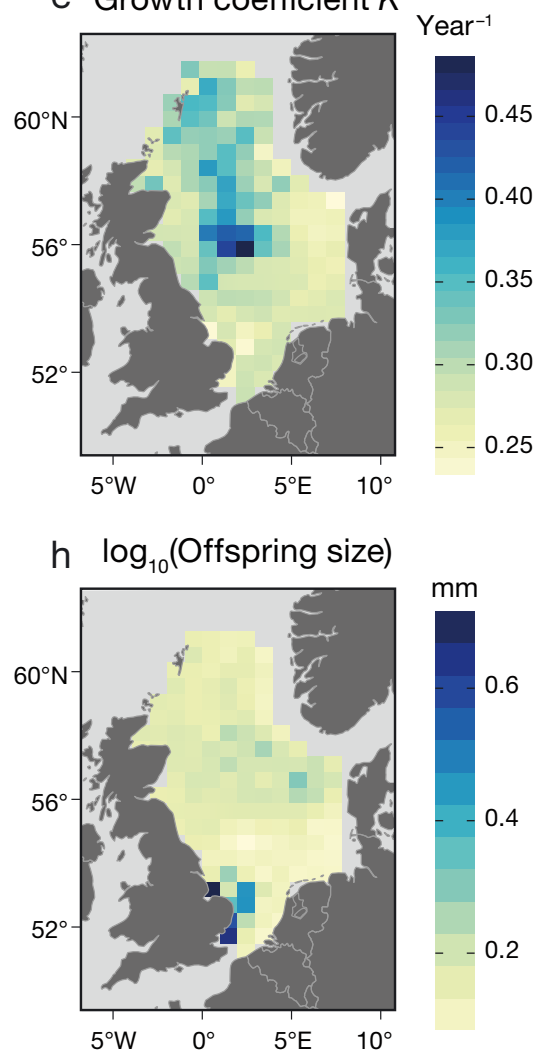

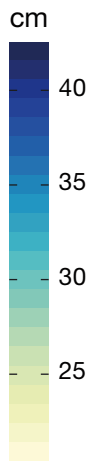

C Age at maturity

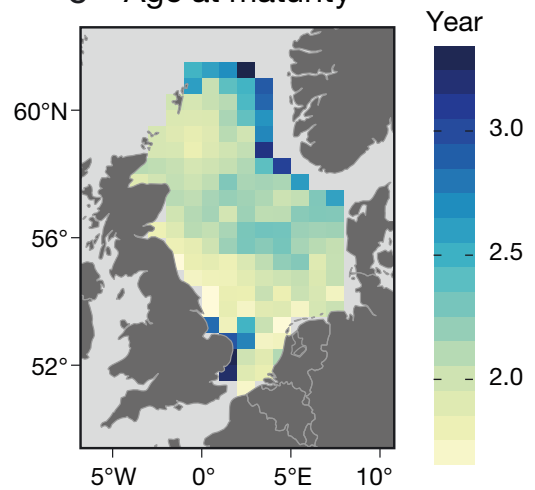

f Trophic level

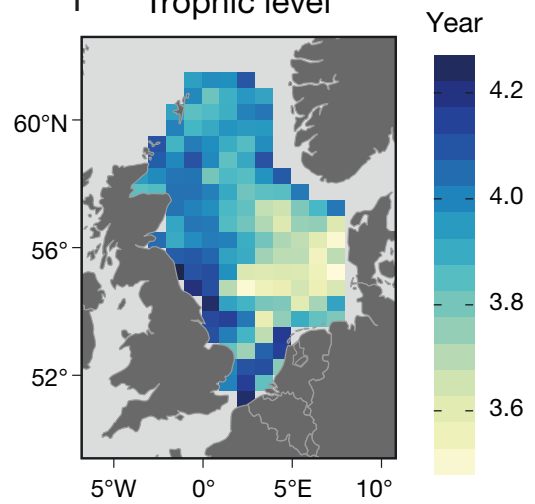

i

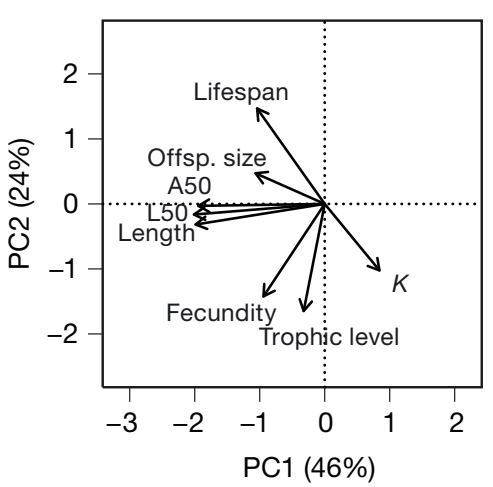

Fig. 3. Spatial distribution of the community-weighted mean (CWM) traits in 147 survey grid cells and principal component analysis of the 8 spatial trait patterns. Spatial patterns of the CWMs of (a) length, (b) length at maturity, (c) age at maturity, (d) lifespan, (e) growth coefficient $K_{r}$ (f) trophic level, (g) fecundity and (h) offspring size (log10-transformed). (i) Ordination plot demonstrating the relationships between the 8 spatial trait patterns. First and second principal components (PC1, PC2) explained 46 and $24 \%$ of the variation, respectively. Offsp. size: offspring size; A50: age at maturity; L50: length at maturity

plained by the models. The total explained deviance was the lowest for the growth coefficient $K$, trophic level and offspring size. This indicates that their temporal variation was poorly explained by the environmental variables included and that their RVI scores should be interpreted with caution. The temporal trends in length, age and length at maturity, lifespan and fecundity were best explained by the PCI, as indi- cated by RVI scores $>0.8$ (Table 2). These traits showed negative non-linear relationships with the PCI, indicating declining values with increasing PCI (Fig. S2 in the Supplement). Winter bottom temperature was another important predictor for length, and age and length at maturity (RVI $>0.9$ ), where years with high CWMs of these traits generally corresponded to lower temperatures (Fig. S2). Lifespan and 
a

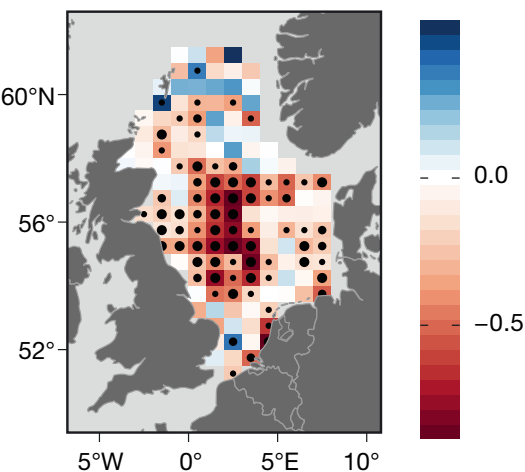

d Lifespan
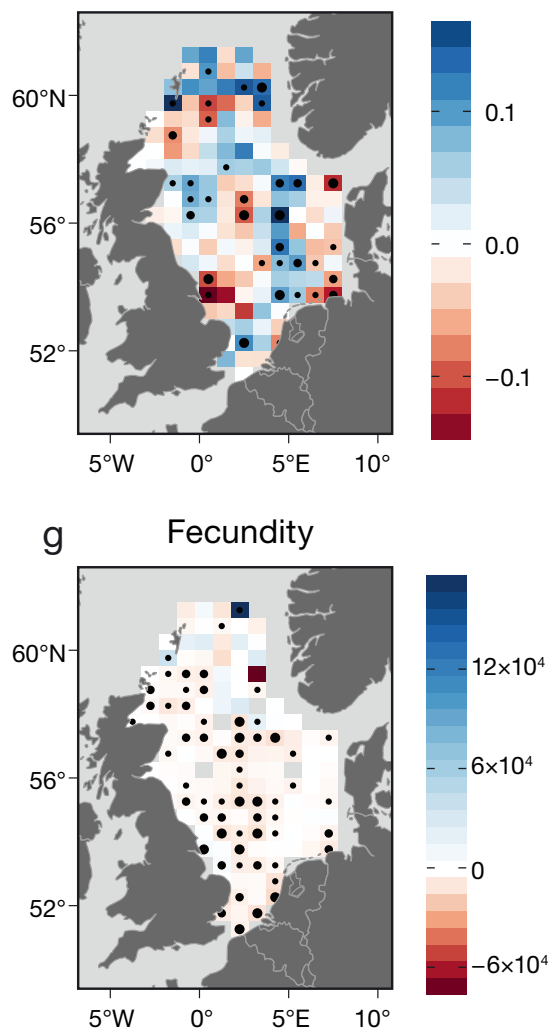

b Length at maturity

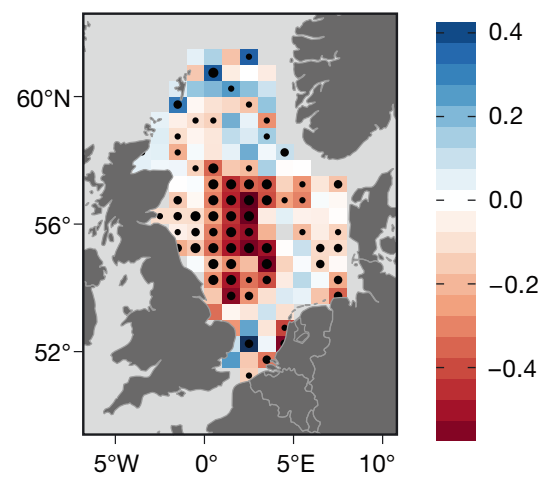

e Growth coefficient $K$

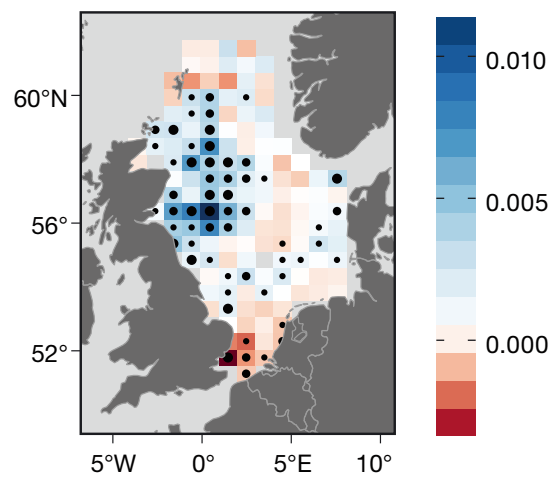

h Offspring size

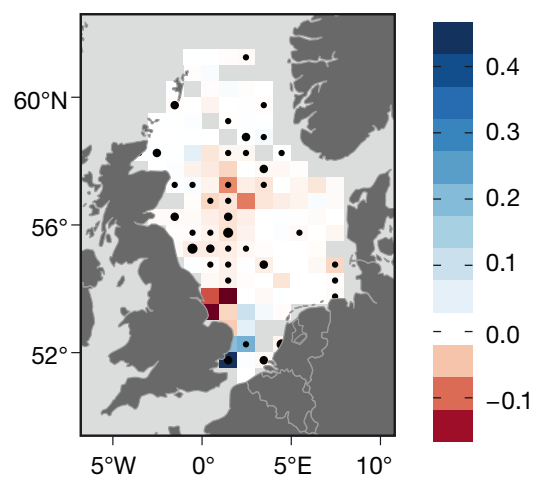

C Age at maturity

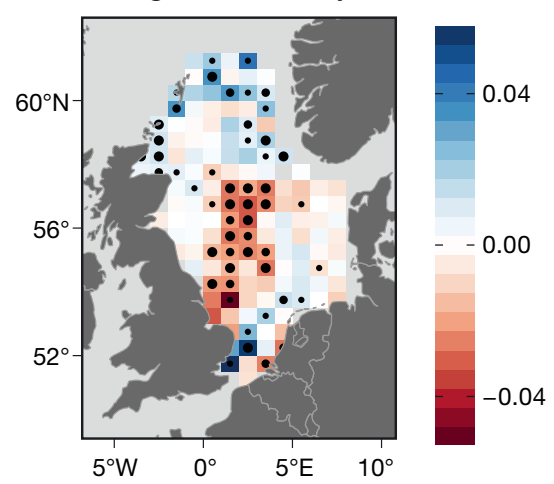

f Trophic level

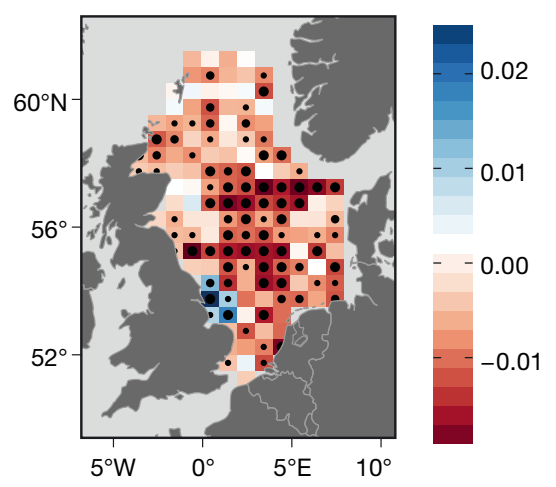

i

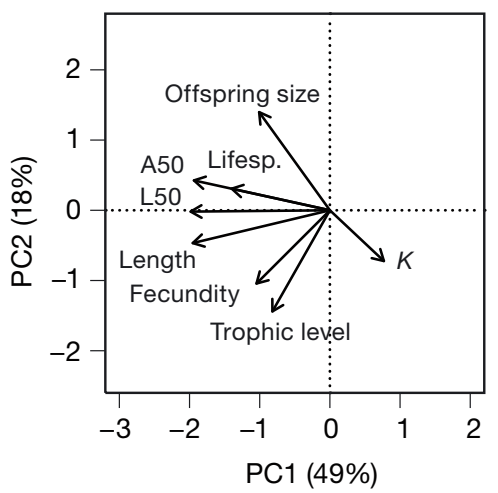

Fig. 4. Slopes of the temporal linear regressions per survey grid cell performed on the community-weighted mean (CWM) traits, and principal component analysis of the slopes of the linear regressions. Linear regressions were performed on the time series of the CWM traits per survey grid cell to indicate spatio-temporal trait patterns. The slopes of the regressions are plotted for (a)

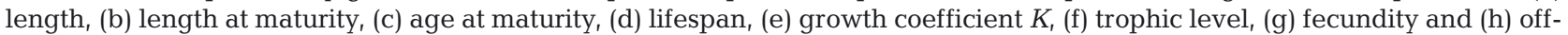
spring size. Red colours indicate a negative slope and blue colours indicate a positive slope. Circles indicate a significant temporal trend (small: $\mathrm{p}<0.05$, medium: $\mathrm{p}<0.01$, large: $\mathrm{p}<0.001$ ). (i) Ordination plot demonstrating the relationships between the slopes of the linear regressions performed for each CWM trait. First and second principal components (PC1, PC2) explained 49 and $18 \%$ of the variation, respectively. Lifesp.: lifespan; A50: age at maturity; L50: length at maturity

fecundity responded non-linearly to temperature (Fig. S2), which was also an important predictor of these traits $(\mathrm{RVI}=0.65)$. Salinity obtained high RVI scores for age and length at maturity, lifespan and the growth coefficient $K$, where years with higher salinity corresponded to higher CWMs of these traits (Fig. S2).
Although the RVI of salinity was relatively high for fecundity (RVI $=0.65$ ), no clear positive or negative relationship was detected (Fig. S2). Most traits did not reveal any strong relationships with seasonality in temperature (Table 2), except for a weak negative relationship with lifespan and fecundity $(\mathrm{RVI}=0.42)$. 
Table 2. Relative variable importance (RVI) values of the environmental predictors for each modelled time series of community mean traits. RVI $\geq 0.5$ shown in bold. The bottom row presents the explained deviance, expressed as adjusted $\mathrm{R}^{2}$, of the full model of each trait (i.e. model including all predictors). The weighted mean RVI in the last column is the average RVI for each predictor over all modelled traits weighted by the $\mathrm{R}^{2}$-values of the full models. The environmental predictors were the phytoplankton colour index (PCI), winter bottom temperature and salinity, and seasonality (difference between summer and winter bottom temperature). For trophic level and growth coefficient $K$, generalized additive mixed models were performed to correct for temporal autocorrelation. The other traits without temporal autocorrelation were modelled using generalized additive models

\begin{tabular}{|c|c|c|c|c|c|c|c|c|c|}
\hline \multirow{2}{*}{$\begin{array}{l}\text { Predictor } \\
\text { Traits: }\end{array}$} & \multirow[b]{2}{*}{ Length } & \multirow[b]{2}{*}{$\begin{array}{l}\text { Length at } \\
\text { maturity }\end{array}$} & \multirow[b]{2}{*}{$\begin{array}{l}\text { Age at } \\
\text { maturity }\end{array}$} & \multirow{2}{*}{$\begin{array}{l}\text { RVI } \\
\text { Lifespan }\end{array}$} & \multirow[b]{2}{*}{$K$} & \multirow[b]{2}{*}{$\begin{array}{c}\text { Trophic } \\
\text { level }\end{array}$} & \multirow[b]{2}{*}{ Fecundity } & \multirow[b]{2}{*}{$\begin{array}{l}\text { Offspring } \\
\text { size }\end{array}$} & \multirow{2}{*}{$\begin{array}{l}\text { Weighted } \\
\text { mean RVI }\end{array}$} \\
\hline & & & & & & & & & \\
\hline PCI & 1.00 & 1.00 & 1.00 & 0.88 & 0.04 & 0.48 & 0.88 & 0.23 & 0.97 \\
\hline Temperature & 0.90 & 0.99 & 0.92 & 0.65 & 0.04 & 0.39 & 0.65 & 0.23 & 0.86 \\
\hline Salinity & 0.22 & 0.76 & 0.95 & 0.65 & 0.73 & 0.15 & 0.65 & 0.22 & 0.65 \\
\hline Seasonality & 0.19 & 0.16 & 0.26 & 0.42 & 0.05 & 0.08 & 0.42 & 0.31 & 0.25 \\
\hline $\mathrm{R}^{2}$ full model & 0.60 & 0.78 & 0.57 & 0.42 & 0.01 & 0.06 & 0.50 & 0.01 & \\
\hline
\end{tabular}

The spatial models of trophic level, lifespan, fecundity and the growth coefficient $K$ had the highest explained deviance of all traits (Table 3). The spatial patterns in offspring size, length, and age and length at maturity were only marginally explained. Therefore, their RVI scores should be interpreted with caution. Depth was an important spatial predictor for trophic level, fecundity, the growth coefficient $K$ and lifespan (RVI > 0.8; Table 3). The first 3 of these traits increased with depth, although trophic level and the growth coefficient $K$ levelled off at around $100 \mathrm{~m}$. Inversely, lifespan decreased until approximately $100 \mathrm{~m}$ depth (Fig. S3 in the Supplement). Seasonality in temperature was an important predictor for explaining the spatial trait patterns of lifespan and trophic level (RVI > 0.7). Lifespan decreased with seasonality, whereas trophic level showed a non-linear positive relationship with seasonality (Fig. S3). The spatial patterns of trophic level and fecundity were well explained by winter bottom temperature (RVI > 0.6), where the CWM of these traits increased with temperature (Fig. S3). Length and length at maturity were best explained by winter bottom temperature, showing positive relationships (Fig. S3), but note the low explained deviance of the models for these traits. Winter bottom salinity was of minor importance for all traits, except trophic level (RVI = 0.67) which decreased non-linearly with increasing

Table 3. Relative variable importance (RVI) of the environmental and fishing predictors for each modelled spatial pattern of community mean traits. RVI $\geq 0.5$ is in bold. The bottom row presents the explained deviance, expressed as adjusted $\mathrm{R}^{2}$, of the full model of each trait (i.e. model including all predictors). The weighted mean RVI in the last column is the average RVI for each predictor over all modelled traits weighted by the $\mathrm{R}^{2}$-values of the full models. The predictor variables were depth, seasonality (difference between summer and winter bottom temperature), winter bottom temperature and salinity, phytoplankton colour index (PCI), substrate richness, otter trawl effort and beam trawl effort. All models were generalized additive mixed models

\begin{tabular}{|c|c|c|c|c|c|c|c|c|c|}
\hline \multirow{2}{*}{$\begin{array}{l}\text { Predictor } \\
\text { Traits: }\end{array}$} & \multirow[b]{2}{*}{ Length } & \multirow[b]{2}{*}{$\begin{array}{l}\text { Length at } \\
\text { maturity }\end{array}$} & \multirow[b]{2}{*}{$\begin{array}{l}\text { Age at } \\
\text { maturity }\end{array}$} & \multirow{2}{*}{$\begin{array}{l}\text { RVI } \\
\text { Lifespan }\end{array}$} & \multirow[b]{2}{*}{$K$} & \multirow[b]{2}{*}{$\begin{array}{c}\text { Trophic } \\
\text { level }\end{array}$} & \multirow[b]{2}{*}{ Fecundity } & \multirow[b]{2}{*}{$\begin{array}{l}\text { Offspring } \\
\text { size }\end{array}$} & \multirow{2}{*}{$\begin{array}{l}\text { Weighted } \\
\text { mean RVI }\end{array}$} \\
\hline & & & & & & & & & \\
\hline Depth & 0.14 & 0.36 & 0.31 & 0.98 & 0.99 & 0.81 & 0.99 & 0.25 & 0.88 \\
\hline Temperature & 0.84 & 0.58 & 0.30 & 0.29 & 0.24 & 0.85 & 0.68 & 0.12 & 0.51 \\
\hline Seasonality & 0.12 & 0.16 & 0.48 & 0.96 & 0.06 & 0.71 & 0.10 & 0.21 & 0.46 \\
\hline Otter trawl effort & 0.11 & 0.10 & 0.11 & 0.11 & 0.97 & 0.23 & 0.08 & 0.24 & 0.32 \\
\hline PCI & 0.17 & 0.11 & 0.13 & 0.24 & 0.99 & 0.03 & 0.09 & 0.20 & 0.31 \\
\hline Salinity & 0.18 & 0.19 & 0.26 & 0.08 & 0.12 & 0.67 & 0.28 & 0.14 & 0.30 \\
\hline Substrate richness & 0.13 & 0.18 & 0.40 & 0.09 & 0.05 & 0.27 & 0.09 & 0.24 & 0.14 \\
\hline Beam trawl effort & 0.19 & 0.10 & 0.10 & 0.15 & 0.09 & 0.03 & 0.08 & 0.14 & 0.09 \\
\hline $\mathrm{R}^{2}$ full model & 0.02 & 0.05 & 0.05 & 0.56 & 0.51 & 0.63 & 0.52 & 0.09 & \\
\hline
\end{tabular}


salinity. The PCI was only an important predictor for the growth coefficient $K(\mathrm{RVI}=0.99)$, where areas with higher PCI were associated with higher growth coefficients $K$. Neither substrate richness nor beam and otter trawl effort statistically explained a great deal of spatial variation in CWM traits, except for the growth coefficient $K(\mathrm{RVI}=0.97)$, which had lower values in areas with higher otter trawl effort (Fig. S3).

\section{DISCUSSION}

\subsection{Trait patterns in time and space}

The long-term changes observed across traits indicate a pronounced change in fish community composition in the North Sea. More specifically, the community shifted from large, slow-growing, late-maturing, long-lived and highly fecund species feeding at high trophic levels towards smaller, faster-growing, earlier-maturing, shorter-living and less fecund species that feed at a slightly lower trophic level. These findings largely correspond to previous studies where the identified temporal changes in individual community mean traits of North Sea fish were attributed either to fishing, increasing sea temperatures or a combination of both (Jennings et al. 1998, 1999a, 2002, Greenstreet et al. 1999, 2012, Rogers \& Ellis 2000, Nicholson \& Jennings 2004, Piet \& Jennings 2005, Engelhard et al. 2011, ter Hofstede \& Rijnsdorp 2011).

Interestingly, the temporal changes in CWM traits were not uniformly distributed in space, but differed markedly between areas (Fig. 4). The majority of significant trends were located in the central North Sea, suggesting that the spatially averaged trends in traits (Fig. 2) are largely driven by changes in this area. Similarly, previous studies on the LFI demonstrated pronounced spatial variation and significant declines, primarily in the central North Sea (Engelhard et al. 2015, Marshall et al. 2016). These declines were partially explained by the northward shift of some large-sized species with high biomass, such as Atlantic cod, likely in response to both fishing and climate change (Engelhard et al. 2014, 2015). Since cod matures at an intermediate age and at a large size, its northward shift has likely also contributed to the community-wide changes in age and length at maturity presented in this study.

In addition to the marked temporal changes in traits, our results demonstrate considerable spatial structuring in trait composition throughout the area, following known spatial patterns in species composition in the North Sea (Daan et al. 1990, Callaway et al. 2002). In general, sub-communities along the Norwegian trench were primarily composed of large, late-maturing, long-living and slow-growing species feeding at high trophic levels, while sub-communities in the southern parts of the area were dominated by smaller, faster-growing species feeding on lower trophic levels. While previous studies suggest a marked south-to-north gradient in fish biodiversity and species composition in the North Sea (Callaway et al. 2002, Dencker et al. 2017), the spatial patterns observed for individual traits did not show such a pronounced latitudinal gradient. Hence, areas with different richness and species composition (Daan et al. 1990, Callaway et al. 2002, Dencker et al. 2017) can comprise communities that are on average rather similar in terms of traits. Conversely, areas with similar biodiversity may have different trait compositions, thereby stressing the importance of studying the underlying trait patterns that make up a community (Weigel et al. 2016). For instance, sub-communities along the Norwegian trench are rather similar in trait structure compared to sub-communities around the Thames and Wash estuaries on the British coast. However, the similarity between these geographically distant areas is primarily visible in terms of size, length/age at maturation, lifespan and trophic level, while fecundity and offspring size show opposite patterns. This indicates that large-sized, higher trophic level species are abundant in both areas, while in the Thames and Wash estuaries these species are characterized by lower fecundity and larger offspring size compared to those in the Norwegian trench. This can largely be explained by differences in species composition, where in the vicinity of the Thames and Wash estuaries large elasmobranchs, that invest in only a few but large and high-quality eggs and offspring, are more abundant (Ellis et al. 2005, Sguotti et al. 2016).

\subsection{Drivers of trait variation in time}

The majority of temporal changes in CWM traits were explained by the PCI, winter bottom temperature and winter bottom salinity (ranked in order of decreasing importance). The pronounced increases in temperature and the PCI (Fig. S4 in the Supplement) were caused by large-scale changes in ocean-atmospheric forcing in the late 1980s leading to an increased flow of warm, nutrient-rich Atlantic waters into the northern North Sea, and subsequently to a higher phytoplankton biomass and a switch in the community composition of zooplankton 
to smaller-sized species (Reid et al. 1998, 2001, Beaugrand 2009). Beaugrand et al. (2003) showed that this shift in zooplankton composition was a major cause of the low survival of larval and juvenile cod. Inversely, the recruitment of flatfish increased after the regime shift and was linked to changes in salinity and temperature (Beaugrand 2004, van Hal et al. 2010, Sparrevohn et al. 2013). The higher phytoplankton biomass and resulting increase in zooplankton production also led to an increase in small, planktivorous fish (Heath 2005). Hence, temperature and PCI have likely influenced the CWM traits indirectly through bottom-up processes, where higher temperature and phytoplankton biomass have favoured smaller and faster-growing species, leading to a decrease in the CWMs of length, age and length at maturity and an increase in the growth coefficient $K$. This is in accordance with previous studies showing community changes towards smaller body length during warm periods (ter Hofstede \& Rijnsdorp 2011), largely resulting from an increase in smaller-sized and faster-growing Lusitanian species, like Mediterranean scaldfish Arnoglossus laterna and grey gurnard Eutrigla gurnardus and a decline in largesized boreal species, like cod and Atlantic wolffish Anarhichas lupus (Beare et al. 2004, Engelhard et al. 2011). The opposite abundance trends of these groups of species have been primarily related to environmental effects acting on recruitment (Beaugrand et al. 2003, Beaugrand 2004, Rijnsdorp et al. 2009) and/or immigration/emigration processes (Perry et al. 2005, Engelhard et al. 2011). In particular, the distribution of Lusitanian species is expanding in the North Sea while large boreal species are expected to move further North in response to warming due to physiological constraints on their metabolism (Rijnsdorp et al. 2009, ter Hofstede et al. 2010, Engelhard et al. 2011).

Although not assessed in this study, the high fishing pressure in the North Sea and its decline since the early 2000s has also influenced the long-term changes in the species and trait composition of the North Sea fish community (Jennings et al. 1999a, Rogers \& Ellis 2000, Wolff 2000, Daan et al. 2005, Bennema \& Rijnsdorp 2015, Engelhard et al. 2015). The direct effect of fishing has been the removal of primarily large species and individuals. Indirectly, this has led to a release of predation pressure on smaller prey species and a subsequent increase in their biomass. Both effects have been argued to underlie the overall decrease in the LFI (Greenstreet et al. 2011, Engelhard et al. 2015), and hence, likely also to the decrease in the CWM of length observed in this study. Because of the correlations in species traits, the decrease in the CWM of age and length at maturity and lifespan during the first part of the study period, as well as the increase in the CWM of the growth coefficient $K$ could partially be understood in light of the direct and indirect effects of fishing (Jennings et al. 1998, 1999a, Greenstreet et al. 2012).

\subsection{Drivers of trait variation in space}

Out of the environmental drivers investigated, depth was one of the best predictors explaining the spatial variation in traits, including lifespan, the growth coefficient $K_{r}$ trophic level and fecundity. Depth is an important determinant of fish species distributions and community structure in the North Sea (Callaway et al. 2002, Dulvy et al. 2008, Fraser et al. 2008, Reiss et al. 2010) Similarly, studies from other regions have reported such trait-depth dependency (Macpherson \& Duarte 1991, Smith \& Brown 2002, Drazen \& Haedrich 2012, Fernandez-Arcaya et al. 2016). The mechanistic understanding for why depth proves a good predictor is likely related to variables of more direct influence that co-vary with depth, e.g. temperature, seasonality, salinity and productivity (Fig. S5 in the Supplement). Indeed, none of the spatial trait patterns, except for offspring size, were best explained by depth alone, but always in combination with some of these variables (Table S3 in the Supplement). Other depth-related factors not accounted for in this study (e.g. light, wind stress and oxygen concentration) could also be of importance (Mindel et al. 2016) and merit future attention.

Winter bottom temperature was positively related to the spatial patterns of trophic level, length and fecundity. One could have expected the opposite, since colder temperatures have generally been shown to favour larger boreal species compared to smaller Lusitanian species (Engelhard et al. 2011, ter Hofstede \& Rijnsdorp 2011). This discrepancy can largely be explained by high biomasses of predatory gadoids with high fecundity, e.g. cod and haddock Melanogrammus aeglefinus, particularly in the deeper northern North Sea, where during winter the bottom temperatures are considerably warmer compared to the shallow southern area (Fig. S5). In summer, however, the temperature pattern in the North Sea is reversed, with the warmest waters located in the shallow south. Hence, investigating potential seasonal shifts in trait distributions should merit attention in future studies. 
Seasonality in bottom temperature was identified as one of the other key drivers explaining the spatial trait patterns. Seasonality generally decreases with depth because of stratification and less mixing of the water column in deeper waters. Hence, the deepest parts of the northern North Sea show temperature differences between summer and winter close to 0 , whereas they reach $>10^{\circ} \mathrm{C}$ in the shallow southern and eastern parts (Fig. S5). Seasonal environments favour small, fast-growing and shortlived species, because of their capability to quickly respond to environmental changes or disturbances (Winemiller \& Rose 1992, Mims et al. 2010, Pecuchet et al. 2017). Contrary to these expectations, the spatial patterns in lifespan demonstrated predominately high values in the shallow, southern North Sea (Fig. 3d), illustrated by a negative relationship between lifespan and depth up to approximately $100 \mathrm{~m}$ (Fig. S3 in the Supplement). These spatial patterns are likely caused by high biomasses of flatfish with a long lifespan, particularly in the shallow southern area, e.g. European plaice Pleuronectes platessa and common sole Solea solea, as well as the exclusion of fast-growing, pelagic species in the analysis. Nevertheless, in addition to depth, seasonality was also included in the best fitting model for lifespan (Table S3), where it displayed a negative linear relationship (Fig. S3). This lends support to the previous findings showing that the proportion of species characterized by short lifespans is higher in seasonal environments.

Phytoplankton biomass, represented by the PCI, was positively related to the spatial variation in the growth coefficient $K$. Our findings are consistent with the work of Pecuchet et al. (2017) showing that highly productive environments select for small and opportunistic, and hence fast-growing, fish species. Phytoplankton biomass also varies with depth and is generally higher in coastal or shallow areas, especially on and around the shallow Dogger Bank located in the central North Sea (Fig. 1, Fig. S5). It has been suggested that the high observed primary production north of the Dogger Bank is caused by the presence of a frontal zone where deeper nutrientrich waters are pushed by tidal forces onto the bank causing peaks in sub-surface primary production in front of the bank (Richardson et al. 2000, Heath \& Beare 2008). This likely explains why this productive but less shallow area north of the Dogger Bank also harbours communities characterized by species with relatively high growth coefficients, such as lesser sandeel Ammodytes marinus and grey gurnard. It is therefore not surprising that both the PCI and depth partially explain the spatial pattern in the CWM of the growth coefficient $K$.

Among the remaining drivers investigated in this study, salinity partially explained the changes in traits over time, but it was a poor predictor of trait variation in space. This is likely due to a narrow range of spatial variation in salinity, with rather high salinities throughout the area $(\sim 32-35$; Fig. S5). Hence, salinities do not reach critical levels below which physiological constraints on adults or early life history stages negatively affect individual species performance (e.g. through osmoregulation or egg buoyancy; MacKenzie et al. 2000, 2007) and community composition at large. Such effects of strong environmental filtering driven by low salinities have been demonstrated in the neighbouring Baltic Sea (Pecuchet et al. 2016), as well as in other brackish, estuarine ecosystems throughout the world (Henriques et al. 2017). Similar to salinity, substrate richness was a poor predictor of trait variation in space. Although greater taxonomic and trait diversity has been associated with substrate-rich areas, likely due to the higher availability of different habitats and niches allowing more species and traits to coexist (Tews et al. 2004, Dencker et al. 2017), substrate richness did not seem to explain any spatial variation at the level of individual community traits. Finally, we found only weak relationships between fishing and the variation of traits in space, with the strongest relationship being between the growth coefficient $K$ and otter trawling. Empirical evidence shows that selective fishing leads to an increase in individuals (or species) with faster growth, smaller size and earlier maturation (Conover \& Munch 2002, Heino \& Godø 2002). However, the fitted spatial relationship was best described as negative (Fig. S3), which was contrary to our expectations and instead most likely suggests fishermen's preferences to fish in areas containing a high proportion of slow-growing species. Overall, the results suggest that the spatial trait composition of the community is more determined by the environmental heterogeneity of the area and that fishing has little additional impact (Szostek et al. 2016).

\subsection{Future directions and conclusions}

Understanding the responses of our oceans to multiple environmental and anthropogenic stressors poses a key challenge for marine ecologists and managers. In this study, we used a trait-based approach to demonstrate how fish community composition in a large and heavily exploited marine ecosystem is spa- 
tially variable and how it has responded to marked changes in the environment in the past. Since the response of communities to environmental changes is mediated by the physiological, morphological and life-history traits of the constituent species, such a trait-based approach leads to a more mechanistic understanding of the impacts of environmental change and exploitation on community composition than when focussing on taxonomic identity alone. Community mean traits can also be used as ecological indicators to detect community-level responses and changes in community-level properties (Greenstreet et al. 2012, Beauchard et al. 2017). Yet, the low degree of variation explained by the models of some traits suggests that other biotic or abiotic drivers should be assessed as well and that not all traits are good candidates for ecological indicators. Expanding our study to other areas and to different spatial scales would be necessary to verify if the observed relationships between traits, the environment and fishing generally hold. Moreover, more attention should be paid to take into account intraspecific trait variation, as it could impact both the spatial and temporal CWM trait patterns. Spatial trait patterns can be affected by the fact that fish undergo large ontogenetic shifts in traits, such as size and diet, and that the spatial distribution of juvenile and adult stages may differ (Heessen et al. 2015). Temporal trends in CWM traits may also be affected by intra-specific variability, especially since several commercial fish species have lowered their age and/or length at maturity and increased their growth coefficient $K$ in response to fishing (Jørgensen et al. 2007).

Besides the community mean, the communityweighted variance of traits may also shed light onto community dynamics, since a strong environmental filter or anthropogenic pressure may reduce the variation around the mean trait value rather than the mean itself (Spasojevic \& Suding 2012, Enquist et al. 2015). Furthermore, trait-based ecologists recently argued for increasing the focus of how traits co-vary along environmental gradients (Poff et al. 2006, Laughlin \& Messier 2015, Dwyer \& Laughlin 2017a). Hence, covariation of traits in marine fish (e.g. length and age at maturity, size and growth rate) across environmental gradients should merit future attention using techniques such as structural equation modelling or joint trait models (Dwyer \& Laughlin 2017b, Wüest et al. 2018).

This study illustrated a pronounced spatial structuring and dramatic long-term change in the trait composition of the North Sea fish community, largely explained by a number of key environmental drivers acting in both space and time, notably depth, temperature, phytoplankton biomass and seasonality. Our findings emphasize the importance of taking both the spatial and temporal dimensions of traits into account when detecting and understanding trends and patterns in community composition and biodiversity, and stress the need for holistic ecosystem-based approaches, including multiple abiotic and biotic processes, to understand and sustainably manage our marine ecosystems in the future (Pikitch et al. 2004). We argue that a trait-based approach, broadened to account for multiple trophic levels, their interactions and responses to drivers, can readily inform and inspire such a development.

Acknowledgements. This work was supported by the MARmaED project, which has received funding from the European Union's Horizon 2020 research and innovation programme under the Marie Sklodowska-Curie grant agreement no. 675997. The results of this publication reflect only the authors' views, and the European Commission is not responsible for any use that may be made of the information it contains. This work also received funding from the VKR Centre for Ocean Life and a VILLUM research grant to M.L. (no. 13159). We thank 4 anonymous reviewers for their constructive comments. We are grateful to Simon Jennings, Georg Engelhard, STECF and Cefas project MF1228 Fizzyfish for providing data on fishing effort in the North Sea. We thank Tom Langbehn for his comments on the manuscript and for creating the bathymetry map of the North Sea. We also thank the scientific and crew members of the bottom trawl surveys for their efforts in collecting the fish survey data.

\section{LITERATURE CITED}

Alofs KM (2016) The influence of variability in species trait data on community-level ecological prediction and inference. Ecol Evol 6:6345-6353

Amante C, Eakins BW (2009) ETOPO1 1 arc-minute global relief model: procedures, data sources and analysis. NOAA Tech Memo NESDIS NGDC-24. National Geophysical Data Center, NOAA, Boulder, CO

Barton K (2016) MuMIn: multi-model inference. R package version 1.15.6. https://cran.r-project.org/web/packages/ MuMIn/index.html

* Baudron AR, Needle CL, Rijnsdorp AD, Marshall TC (2014) Warming temperatures and smaller body sizes: synchronous changes in growth of North Sea fishes. Glob Change Biol 20:1023-1031

Beare DJ, Burns F, Greig A, Jones EG and others (2004) Long-term increases in prevalence of North Sea fishes having southern biogeographic affinities. Mar Ecol Prog Ser 284:269-278

* Beauchard O, Veríssimo H, Queirós AM, Herman PMJ (2017) The use of multiple biological traits in marine community ecology and its potential in ecological indicator development. Ecol Indic 76:81-96

*Beaugrand G (2004) The North Sea regime shift: evidence, causes, mechanisms and consequences. Prog Oceanogr 
60:245-262

Beaugrand G (2009) Decadal changes in climate and ecosystems in the North Atlantic Ocean and adjacent seas. Deep Sea Res II Top Stud Oceanogr 56:656-673

Beaugrand G, Brander KM, Lindley JA, Souissi S, Reid PC (2003) Plankton effect on cod recruitment in the North Sea. Nature 426:661-664

Bennema FP, Rijnsdorp AD (2015) Fish abundance, fisheries, fish trade and consumption in sixteenth-century Netherlands as described by Adriaen Coenen. Fish Res 161: 384-399

Bergstad OA (1990) Ecology of the fishes of the Norwegian Deep: distribution and species assemblages. Neth J Sea Res 25:237-266

Bianchi G, Gislason H, Graham K, Hill L and others (2000) Impact of fishing on size composition and diversity of demersal fish communities. ICES J Mar Sci 57:558-571

Bivand R, Piras G (2015) Comparing implementations of estimation methods for spatial econometrics. J Stat Softw 63:1-36

Bivand RS, Hauke J, Kossowski T (2013) Computing the Jacobian in Gaussian spatial autoregressive models: an illustrated comparison of available methods. Geogr Anal 45:150-179

Borcard D, Gillet F, Legendre P (2011) Numerical ecology with R. Springer-Verlag, New York, NY (series: Use R!)

Burnham KP, Anderson DR (2002) Model selection and multimodel inference - a practical information-theoretic approach, 2nd edn. Springer-Verlag, New York, NY

Callaway R, Alsvåg J, de Boois I, Cotter J and others (2002) Diversity and community structure of epibenthic invertebrates and fish in the North Sea. ICES J Mar Sci 59: 1199-1214

Coleman MA, Bates AE, Stuart-Smith RD, Malcolm HA and others (2015) Functional traits reveal early responses in marine reserves following protection from fishing. Divers Distrib 21:876-887

Coll M, Shannon LJ, Yemane D, Link JS and others (2010) Ranking the ecological relative status of exploited marine ecosystems. ICES J Mar Sci 67:769-786

Coll M, Shannon LJ, Kleisner KM, Juan-Jordá MJ and others (2016) Ecological indicators to capture the effects of fishing on biodiversity and conservation status of marine ecosystems. Ecol Indic 60:947-962

Conover DO, Munch SB (2002) Sustaining fisheries yields over evolutionary time scales. Science 297:94-96

Coull KA, Jermyn AS, Newton AW, Henderson GI, Hall WB (1989) Length/weight relationships for 88 species of fish encountered in the North East Atlantic. Department of Agriculture and Fisheries for Scotland, Aberdeen

Daan N, Bromley P, Hislop J, Nielsen N (1990) Ecology of North Sea fish. Neth J Sea Res 26:343-386

Daan N, Gislason H, Pope JG, Rice JC (2005) Changes in the North Sea fish community: evidence of indirect effects of fishing? ICES J Mar Sci 62:177-188

* Dencker TS, Pécuchet L, Beukhof E, Richardson K, Payne MR, Lindegren M (2017) Temporal and spatial differences between taxonomic and trait biodiversity: causes and consequences. PLOS ONE 12:e0189731

* Drazen JC, Haedrich RL (2012) A continuum of life histories in deep-sea demersal fishes. Deep Sea Res I Oceanogr Res Pap 61:34-42

* Dulvy NK, Rogers SI, Jennings S, Stelzenmüller V, Dye SR, Skjoldal HR (2008) Climate change and deepening of the North Sea fish assemblage: a biotic indicator of warming seas. J Appl Ecol 45:1029-1039

*Dwyer JM, Laughlin DC (2017a) Selection on trait combinations along environmental gradients. J Veg Sci 28: 672-673

*Dwyer JM, Laughlin DC (2017b) Constraints on trait combinations explain climatic drivers of biodiversity: the importance of trait covariance in community assembly. Ecol Lett 20:872-882

* Ellis JR, Cruz-Martínez A, Rackham BD, Rogers SI (2005) The distribution of chondrichthyan fishes around the British Isles and implications for conservation. J Northwest Atl Fish Sci 35:195-213

EMODnet (2015) European Marine Observation Data Network (EMODnet) Seabed Habitats project. European Commission's Directorate-General for Maritime Affairs and Fisheries (DG MARE). www.emodnet-seabedhabitats.eu/ (accessed 8 December 2015)

Engelhard GH, Ellis JR, Payne M, ter Hofstede R, Pinnegar JK (2011) Are ecotypes a meaningful and useful concept for exploring responses to climate change in fish assemblages? ICES J Mar Sci 68:580-591

* Engelhard GH, Righton DA, Pinnegar JK (2014) Climate change and fishing: a century of shifting distribution in North Sea cod. Glob Change Biol 20:2473-2483

*Engelhard GH, Lynam CP, García-Carreras B, Dolder PJ, Mackinson S (2015) Effort reduction and the large fish indicator: spatial trends reveal positive impacts of recent European fleet reduction schemes. Environ Conserv 42: $227-236$

Enquist BJ, Norberg J, Bonser SP, Violle C and others (2015) Scaling from traits to ecosystems: developing a general trait driver theory via integrating trait-based and metabolic scaling theories. In: Pawar S, Woodward G, Dell AI (eds) Advances in ecological research. Elsevier, Amsterdam, p 249-318

Fernandez-Arcaya U, Drazen JC, Murua H, Ramirez-Llodra E and others (2016) Bathymetric gradients of fecundity and egg size in fishes: a Mediterranean case study. Deep Sea Res I 116:106-117

Frainer A, Primicerio R, Kortsch S, Aune M, Dolgov AV, Fossheim M, Aschan MM (2017) Climate-driven changes in functional biogeography of Arctic marine fish communities. Proc Natl Acad Sci USA 114:12202-12207

Fraser HM, Greenstreet SPR, Fryer RJ, Piet GJ (2008) Mapping spatial variation in demersal fish species diversity and composition in the North Sea: accounting for species-and size-related catchability in survey trawls. ICES J Mar Sci 65:531-538

Frelat R, Lindegren M, Dencker TS, Floeter J and others (2017) Community ecology in 3D: Tensor decomposition reveals spatio-temporal dynamics of large ecological communities. PLOS ONE 12:e0188205

Froese R, Pauly D (2017) FishBase. www.fishbase.org (accessed 7 July 2017)

*FFung T, Farnsworth KD, Reid DG, Rossberg AG (2012) Recent data suggest no further recovery in North Sea Large Fish Indicator. ICES J Mar Sci 69:235-239

*Gallucci VF, Quinn TJ (1979) Reparameterizing, fitting, and testing a simple growth model. Trans Am Fish Soc 108: $14-25$

*Garnier E, Cortez A, Billès G, Navas M and others (2004) Plant functional markers capture ecosystem properties during secondary succession. Ecology 85:2630-2637

Greenstreet SPR, Hall SJ (1996) Fishing and the ground-fish assemblage structure in the North Sea: an analysis of 
long-term and spatial trends. J Anim Ecol 65:577-598

Greenstreet SPR, Rogers SI (2006) Indicators of the health of the North Sea fish community: identifying reference levels for an ecosystem approach to management. ICES J Mar Sci 63:573-593

Greenstreet SPR, Spence FE, McMillan JA (1999) Fishing effects in northeast Atlantic shelf seas: patterns in fishing effort, diversity and community structure. V. Changes in structure of the North Sea groundfish species assemblage between 1925 and 1996. Fish Res 40:153-183

Greenstreet SPR, Rogers SI, Rice JC, Piet GJ, Guirey EJ, Fraser HM, Fryer RJ (2011) Development of the EcoQO for the North Sea fish community. ICES J Mar Sci 68:1-11

Greenstreet SPR, Fraser HM, Rogers SI, Trenkel VM, Simpson SD, Pinnegar JK (2012) Redundancy in metrics describing the composition, structure, and functioning of the North Sea demersal fish community. ICES J Mar Sci 69:8-22

Grime JP (1998) Benefits of plant diversity to ecosystems: immediate, filter and founder effects. J Ecol 86:902-910

Halpern BS, Floeter SR (2008) Functional diversity responses to changing species richness in reef fish communities. Mar Ecol Prog Ser 364:147-156

Heath M (2005) Changes in the structure and function of the North Sea fish foodweb, 1973-2000, and the impacts of fishing and climate. ICES J Mar Sci 62:847-868

* Heath MR, Beare DJ (2008) New primary production in northwest European shelf seas, 1960-2003. Mar Ecol Prog Ser 363:183-203

Heessen HJL, Daan N, Ellis JR (2015) Fish atlas of the Celtic Sea, North Sea, and Baltic Sea. Wageningen Academic Publishers, Wageningen

Heino M, Godø OR (2002) Fisheries-induced selection pressures in the context of sustainable fisheries. Bull Mar Sci 70:639-656

Henriques S, Guilhaumon F, Villéger S, Amoroso S and others (2017) Biogeographical region and environmental conditions drive functional traits of estuarine fish assemblages worldwide. Fish Fish 18:752-771

Hiddink JG, ter Hofstede R (2008) Climate induced increases in species richness of marine fishes. Glob Change Biol 14: $453-460$

ICES (International Council for the Exploration of the Sea) (2015) Manual for the International Bottom Trawl Surveys. Series of ICES Survey Protocols SISP 10 IBTS IX. International Council for the Exploration of the Sea, Copenhagen

Jennings S, Reynolds JD, Mills SC (1998) Life history correlates of responses to fisheries exploitation. Proc R Soc B 265:333-339

Jennings S, Greenstreet SPR, Reynolds JD (1999a) Structural change in an exploited fish community: a consequence of differential fishing effects on species with contrasting life histories. J Anim Ecol 68:617-627

Jennings S, Alvsvåg J, Cotter A, Ehrich S and others (1999b) Fishing effects in northeast Atlantic shelf seas: patterns in fishing effort, diversity and community structure. III. International trawling effort in the North Sea: an analysis of spatial and temporal trends. Fish Res 40:125-134

Jennings S, Greenstreet SPR, Hill L, Piet G, Pinnegar J, Warr KJ (2002) Long-term trends in the trophic structure of the North Sea fish community: evidence from stable-isotope analysis, size-spectra and community metrics. Mar Biol 141:1085-1097

Jørgensen C, Enberg K, Dunlop ES, Arlinghaus R and others
(2007) Managing evolving fish stocks. Science 318: $1247-1248$

*Kenny AJ, Skjoldal HR, Engelhard GH, Kershaw PJ, Reid JB (2009) An integrated approach for assessing the relative significance of human pressures and environmental forcing on the status of Large Marine Ecosystems. Prog Oceanogr 81:132-148

* Laughlin DC, Messier J (2015) Fitness of multidimensional phenotypes in dynamic adaptive landscapes. Trends Ecol Evol 30:487-496

Link JS, Yemane D, Shannon LJ, Coll M, Shin YJ, Hill L, Borges MDF (2010) Relating marine ecosystem indicators to fishing and environmental drivers: an elucidation of contrasting responses. ICES J Mar Sci 67:787-795

* Litchman E, Ohman MD, Kiørboe T (2013) Trait-based approaches to zooplankton communities. J Plankton Res 35:473-484

* MacKenzie BR, Hinrichsen HH, Plikshs M, Wieland K, Zezera AS (2000) Quantifying environmental heterogeneity: habitat size necessary for successful development of cod Gadus morhua eggs in the Baltic Sea. Mar Ecol Prog Ser 193:143-156

MacKenzie BR, Gislason H, Möllmann C, Köster FW (2007) Impact of 21st century climate change on the Baltic Sea fish community and fisheries. Glob Change Biol 13: 1348-1367

*Macpherson E, Duarte CM (1991) Bathymetric trends in demersal fish size: Is there a general relationship? Mar Ecol Prog Ser 71:103-112

* Marshall AM, Bigg GR, van Leeuwen SM, Pinnegar JK, Wei HL, Webb TJ, Blanchard JL (2016) Quantifying heterogeneous responses of fish community size structure using novel combined statistical techniques. Glob Change Biol 22:1755-1768

* McGill BJ, Enquist BJ, Weiher E, Westoby M (2006) Rebuilding community ecology from functional traits. Trends Ecol Evol 21:178-185

Millennium Ecosystem Assessment (2005) Ecosystems and human well-being: biodiversity synthesis. World Resources Institute, Washington, DC

Nims MC, Olden JD, Shattuck ZR, Poff NL (2010) Life history trait diversity of native freshwater fishes in North America. Ecol Freshw Fish 19:390-400

Mindel BL, Webb TJ, Neat FC, Blanchard JL (2016) A traitbased metric sheds new light on the nature of the body size-depth relationship in the deep sea. J Anim Ecol 85: 427-436

* Mouillot D, Graham NAJ, Villéger S, Mason NWH, Bellwood DR (2013) A functional approach reveals community responses to disturbances. Trends Ecol Evol 28:167-177

Nicholson MD, Jennings S (2004) Testing candidate indicators to support ecosystem-based management: the power of monitoring surveys to detect temporal trends in fish community metrics. ICES J Mar Sci 61:35-42

*Nogués-Bravo D (2009) Comparing regression methods to predict species richness patterns. Web Ecol 9:58-67

*Núñez-Riboni I, Akimova A (2015) Monthly maps of optimally interpolated in situ hydrography in the North Sea from 1948 to 2013. J Mar Syst 151:15-34

*Pauly D, Christensen V, Dalsgaard J, Froese R, Torres F (1998) Fishing down marine food webs. Science 279: 860-863

* Pecuchet L, Törnroos A, Lindegren M (2016) Patterns and drivers of fish community assembly in a large marine ecosystem. Mar Ecol Prog Ser 546:239-248 
Pecuchet L, Lindegren M, Hidalgo M, Delgado M and others (2017) From traits to life history strategies: deconstructing fish community composition across European Seas. Glob Ecol Biogeogr 26:812-822

*Perry AL, Low PJ, Ellis JR, Reynolds JD (2005) Climate change and distribution shifts in marine fishes. Science 308:1912-1915

Piet GJ, Jennings S (2005) Response of potential fish community indicators to fishing. ICES J Mar Sci 62:214-225

*Pikitch EK, Santora C, Babcock EA, Bakun A and others (2004) Ecosystem-based fishery management. Science 305:346-347

* Poff NL, Olden JD, Vieira NKM, Finn DS, Simmons MP, Kondratieff BC (2006) Functional trait niches of North American lotic insects: traits-based ecological applications in light of phylogenetic relationships. J N Am Benthol Soc 25:730-755

*Poloczanska ES, Burrows MT, Brown CJ, Garcia Molinos J and others (2016) Responses of marine organisms to climate change across oceans. Front Mar Sci 3:62

Pörtner HO, Karl DM, Boyd PW, Cheung WWL and others (2014) Ocean systems. In: Barros VR, Field CB, Dokken DJ, Mastrandrea MD and others (eds) Climate change 2014: impacts, adaptation, and vulnerability. Part A: global and sectoral aspects. Contribution of Working Group II to the Fifth Assessment Report of the Intergovernmental Panel on Climate Change. Cambridge University Press, Cambridge, p 411-484

R Core Team (2017) R: a language and environment for statistical computing. Version 3.4.0. R Foundation for Statistical Computing, Vienna

Reid PC, Edwards M, Hunt HG, Warner AJ (1998) Phytoplankton change in the North Atlantic. Nature 391:546

Reid PC, Holliday NP, Smyth TJ (2001) Pulses in the eastern margin current and warmer water off the north west European shelf linked to North Sea ecosystem changes. Mar Ecol Prog Ser 215:283-287

Reiss H, Degraer S, Duineveld GCA, Kröncke I and others (2010) Spatial patterns of infauna, epifauna, and demersal fish communities in the North Sea. ICES J Mar Sci 67 : 278-293

Rice J, Gislason H (1996) Patterns of change in the size spectra of numbers and diversity of the North Sea fish assemblage, as reflected in surveys and models. ICES J Mar Sci 53:1214-1225

Richardson K, Visser AW, Pedersen FB (2000) Subsurface phytoplankton blooms fuel pelagic production in the North Sea. J Plankton Res 22:1663-1671

Ricotta C, Moretti M (2011) CWM and Rao's quadratic diversity: a unified framework for functional ecology. Oecologia 167:181-188

Rijnsdorp AD, Peck MA, Engelhard GH, Möllmann C, Pinnegar JK (2009) Resolving the effect of climate change on fish populations. ICES J Mar Sci 66:1570-1583

Robinson LA, Greenstreet SPR, Reiss H, Callaway R and others (2010) Length-weight relationships of 216 North Sea benthic invertebrates and fish. J Mar Biol Assoc UK 90:95-98

Rogers SI, Ellis JR (2000) Changes in the demersal fish assemblages of British coastal waters during the 20th century. ICES J Mar Sci 57:866-881

Ruppert JLW, Vigliola L, Kulbicki M, Labrosse P, Fortin MJ, Meekan MG (2018) Human activities as a driver of spatial variation in the trophic structure of fish communities on Pacific coral reefs. Glob Change Biol 24:e67-e79
SAHFOS (Sir Alister Hardy Foundation for Ocean Science) (2016) Phytoplankton Colour Index data from the North Sea from 1958-2014 provided by SAHFOS. https://www. cprsurvey.org/, doi:10.7487/2016.109.1.968

Sguotti C, Lynam CP, García-Carreras B, Ellis JR, Engelhard GH (2016) Distribution of skates and sharks in the North Sea: 112 years of change. Glob Change Biol 22:2729-2743

Simpson SD, Jennings S, Johnson MP, Blanchard JL, Schön PJ, Sims DW, Genner MJ (2011) Continental shelf-wide response of a fish assemblage to rapid warming of the sea. Curr Biol 21:1565-1570

* Smith KF, Brown JH (2002) Patterns of diversity, depth range and body size among pelagic fishes along a gradient of depth. Glob Ecol Biogeogr 11:313-322

* Sparrevohn CR, Lindegren M, Mackenzie BR (2013) Climateinduced response of commercially important flatfish species during the 20th century. Fish Oceanogr 22:400-408

Spasojevic MJ, Suding KN (2012) Inferring community assembly mechanisms from functional diversity patterns: the importance of multiple assembly processes. J Ecol 100:652-661

Szostek CL, Murray LG, Bell E, Rayner G, Kaiser MJ (2016) Natural vs. fishing disturbance: drivers of community composition on traditional king scallop, Pecten maximus, fishing grounds. ICES J Mar Sci 73:i70-i83

* ter Hofstede R, Rijnsdorp AD (2011) Comparing demersal fish assemblages between periods of contrasting climate and fishing pressure. ICES J Mar Sci 68:1189-1198

*ter Hofstede R, Hiddink JG, Rijnsdorp AD (2010) Regional warming changes fish species richness in the eastern North Atlantic Ocean. Mar Ecol Prog Ser 414:1-9

*Tews J, Brose U, Grimm V, Tielbörger K, Wichmann MC, Schwager M, Jeltsch F (2004) Animal species diversity driven by habitat heterogeneity/diversity: the importance of keystone structures. J Biogeogr 31:79-92

* van Denderen PD, Hintzen NT, Rijnsdorp AD, Ruardij P, van Kooten T (2014) Habitat-specific effects of fishing disturbance on benthic species richness in marine soft sediments. Ecosystems 17:1216-1226

* van Hal R, Smits K, Rijnsdorp AD (2010) How climate warming impacts the distribution and abundance of two small flatfish species in the North Sea. J Sea Res 64:76-84

Verberk WCEP, van Noordwijk CGE, Hildrew AG (2013) Delivering on a promise: integrating species traits to transform descriptive community ecology into a predictive science. Freshw Sci 32:531-547

* Verreycken H, van Thuyne G, Belpaire C (2011) Lengthweight relationships of 40 freshwater fish species from two decades of monitoring in Flanders (Belgium). J Appl Ichthyol 27:1416-1421

* Violle C, Navas ML, Vile D, Kazakou E, Fortunel C, Hummel I, Garnier E (2007) Let the concept of trait be functional! Oikos 116:882-892

* Violle C, Reich PB, Pacala SW, Enquist BJ, Kattge J (2014) The emergence and promise of functional biogeography. Proc Natl Acad Sci USA 111:13690-13696

*Ward TD, Algera DA, Gallagher AJ, Hawkins E and others (2016) Understanding the individual to implement the ecosystem approach to fisheries management. Conserv Physiol 4:cow005

*Weigel B, Blenckner T, Bonsdorff E (2016) Maintained functional diversity in benthic communities in spite of diverging functional identities. Oikos 125:1421-1433

*Wiedmann MA, Aschan M, Certain G, Dolgov A and others (2014) Functional diversity of the Barents Sea fish com- 
munity. Mar Ecol Prog Ser 495:205-218

Winemiller KO, Rose KA (1992) Patterns of life-history diversification in North American fishes: implications for population regulation. Can J Fish Aquat Sci 49:2196-2218

Wolff WJ (2000) The south-eastern North Sea: losses of vertebrate fauna during the past 2000 years. Biol Conserv 95:209-217

Wood SN (2006) Generalized additive models: an introduction with R. CRC Press, Boca Raton, FL

Wood SN (2011) Fast stable restricted maximum likelihood

Editorial responsibility: Konstantinos Stergiou,

Thessaloniki, Greece and marginal likelihood estimation of semiparametric generalized linear models. J R Stat Soc 73:3-36

* Wüest RO, Münkemüller T, Lavergne S, Pollock LJ, Thuiller W (2018) Integrating correlation between traits improves spatial predictions of plant functional composition. Oikos 127:472-481

Zuur AF, Ieno EN, Walker NJ, Saveliev AA, Smith GM (2009) Mixed effects models and extensions in ecology with R. Springer-Verlag, New York, NY (series: Statistics for biology and health)

Submitted: November 24, 2017; Accepted: November 18, 2018 Proofs received from author(s): January 17, 2019 